\title{
KARAKTERISTIK CAMPURAN ASPAL HRS-BASE MENGGUNAKAN AGREGAT KASAR BATU KAPUR ASAL TINORING
}

\author{
Natser Istiqlal Chalid ${ }^{1}$ \\ ${ }^{1}$ Dosen FT Universitas Andi Djemma Palopo \\ 1natser.chalid@yahoo.com
}

\begin{abstract}
Abstrak
Saat ini ketersediaan batu sungai di Tana Toraja sudah sangat menipis, oleh karena itu dibutuhkan material alternatif sebagai agregat kasar pada pembuatan campuran aspal. Penelitian ini menggunakan batu kapur asal Tinoring sebagai agregat kasar pembuatan campuran aspal HRS Base. Penelitian dilakukan dengan menguji karakteristik batu kapur lalu dilanjutkan dengan uji Marshall dan Marshall terhadap benda uji HRS-Base dengan kadar aspal 5\%, 6\%, 7\%, 8\% dan 9\%. Hasil penelitian menunjukkan batu kapur Tinoring memenuhi syarat sebagai agregat kasar campuran aspal HRS-Base. Dan hasil uji Marshall menunjukkan kadar aspal optimum sebesar 7\%.
\end{abstract}

Kata kunci : HRS Base, Batu Kapur, Uji Marshall

\section{PENDAHULUAN}

Pembangunan jaringan jalan setiap tahun gencar dilakukan, demi menunjang pembangunan sampaI ke daerah terpencil. Namun, kebutuhan agregat kasar sebagai salah satu bahan pembuat campuran aspal panas saat ini sangat sulit didapatkan di Tana Toraja. Ketersediaan batu sungai sudah sangat menipis. Oleh karena itu dibutuhkan penelitian terhadap material lain yang dapat digunakan sebagai bahan agregat kasar. Tinoring merupakan pegunungan yang mempunyai deposit batu kapur yang cukup banyak. Penelitian ini mencoba mengetahui bagaimana karakteristik campuran aspal yang menggunakan batu kapur Tinoring sebagai agregat kasar untuk campuran aspal HRS Base. Tujuan dari penelitian ini adalah (1) untuk mengetahui karakterisitk batu kapur asal Tinoring untuk campuran HRS-Base, dan (2) untuk mengetahui kadar aspal optimum (KAO) pada campuran HRS-base dengan agregat kasar batu kapur Tinoring.

Hot Rolled Sheet (HRS) adalah jenis campuran beraspal yang menggunakan agregat bergradasi senjang. Di dalam Hot Rolled Sheet (HRS) hanya terdapat sedikit agregat berukuran sedang $(2,3 \mathrm{~mm}-10 \mathrm{~mm})$, dan terdiri dari matriks pasir, filler, dan aspal, dimana agregat kasar biasanya berukuran $14 \mathrm{~mm}$, tercampur didalamnya. Gradasi senjang inilah yang memberikan Hot Rolled Sheet (HRS) sifat ketahanan terhadap cuaca dan memiliki permukaan yang awet, yang dapat mengakomodasi lalu lintas berat tanpa terjadi retak. HRS/Lataston terdiri dari dua macam campuran yaitu Lataston lapis pondasi (HRS-Base) dan Lataston Lapis permukaan (HRS-Wearing course). Ukuran maksimum agregat masing-masing campuran adalah $19 \mathrm{~mm}$. Lataston Lapis Pondasi (HRS-Base) mempunyai proporsi fraksi agregat kasar lebih besar daripada lataston lapis permukaan (HRS-Wearing course). Campuran ini ditujukan untuk jalan dengan lalu lintas rencana kurang dari 1.000.000. ESA. Untuk mendapatkan hasil yang memuaskan, maka campuran harus dirancang sampai memenuhi ketentuan yang diberikan dalam spesifikasi.

Fungsi dari Hot Rolled Sheet (HRS) adalah sebagai lapis penutup untuk mencegah masuknya air dari permukaan kedalam konstruksi perkerasan, sehingga dapat mempertahankan kekuatan konstruksi sampai tingkat tertentu. Keistimewaan Hot Rolled Sheet (HRS) yaitu mempunyai keawetan tinggi tetapi stabilitasnya rendah. Spesifikasi Jalan dan Jembatan Bina Marga, membedakan antara HRS-WC 
dan HRS-Base yang terletak pada rongga dalam agregat minimumnya, yaitu $18 \%$ pada HRS-WC dan $17 \%$ pada HRS-Base, dan bila diuji dengan metode marshall harus memenuhi persyaratan campuran seperti ditunjukkan pada Tabel 3.1.

Tabel 1. Spesifikasi teknis campuran Lataston

\begin{tabular}{|c|c|c|c|}
\hline \multicolumn{2}{|l|}{ Sifat Campuran } & \multicolumn{2}{|c|}{$\begin{array}{c}\text { Lataston / } \\
\text { HRS }\end{array}$} \\
\hline & & WC & Base \\
\hline Penyerapan kadar aspal (\%) & Max & & \\
\hline Jumlah Tumbukan Per Bidang & & & \\
\hline \multirow{2}{*}{ Rongga Dalam Campuran (VIM) (\%) } & Min & \multicolumn{2}{|c|}{3,0} \\
\hline & Max & \multicolumn{2}{|c|}{6,0} \\
\hline Rongga Dalam Agregat (VMA) (\%) & Min & 18 & 17 \\
\hline Rongga Terisi Aspal (VFA) (\%) & Min & \multicolumn{2}{|c|}{68} \\
\hline Stabilitas Marshall (kg) & Min & \multicolumn{2}{|c|}{800} \\
\hline Pelelehan/Flow (mm) & Min & \multicolumn{2}{|c|}{3} \\
\hline Marshall Qutient (kg/mm) & Min & \multicolumn{2}{|c|}{250} \\
\hline $\begin{array}{l}\text { Stabilitas Marshall Sisa (\%) setelah perendaman } 24 \text { Jam, } \\
60{ }^{\circ} \mathrm{C}\end{array}$ & Min & \multicolumn{2}{|c|}{75} \\
\hline $\begin{array}{l}\text { Rongga dalam campuran (\%) pada kepadatan membal } \\
\text { (refusal) }\end{array}$ & Min & \multicolumn{2}{|c|}{2} \\
\hline
\end{tabular}

Sumber : Spesifikasi Jalan \& Jembatan Bina Marga

Salah satu hal yang cukup berpengaruh terhadap karakteristik HRS adalah rancangan campuran, baik itu pada saat pencampuran, penghamparan, pemadatan, atau pada saat pemanfaatannya. Suatu rancangan campuran dengan proporsi tertentu akan menghasilkan karakteristik campuran tertentu pula. Karakteristik yang harus dimiliki oleh campuran HRS-Base adalah :

a) Stabilitas

Stabilitas lapisan perkerasan jalan adalah kemampuan lapisan perkerasan menerima beban lalu lintas tanpa terjadi perubahan bentuk seperti gelombang, alur maupun bleeding (pengumpulan aspal di permukaan perkerasan).

b) Durabilitas (keawetan/daya tahan)

Durabilitas diperlukan pada lapisan permukaan sehingga lapisan mampu menahan keausan akibat pengaruh cuaca, air dan perubahan suhu maupun keausan akibat gesekan kendaraan. Faktor-faktor yang mempengaruhi durabilitas lapisan HRS - Base adalah:

1) Film atau selimut aspal. Film aspal yang tebal dapat menghasilkan lataston yang berdurabilitas tinggi, tetapi kemungkinan terjadi bleeding yang tinggi.

2) VIM kecil sehingga hasil kedap air dan udara tidak masuk kedalam campuran yang menyebabkan terjadinya oksidasi dan aspal menjadi rapuh.

3) VMA besar sehingga, film aspal dapat dibuat tebal. Jika VMA dan VIM kecil serta kadar aspal tinggi kemungkinan terjadinya bleeding (pengumpulan aspal di permukaan perkerasan) besar. Yang dimaksud dengan VIM (Void In Mix) adalah pori dalam campuran yang telah dipadatkan atau banyaknya rongga udara yang ada dalam campuran HRS. Sedangkan VMA (Void in Mix 
Agregate) adalah ruang diantara partikel agregat pada suatu perkerasan beraspal, termasuk rongga udara dan volume aspal efektif (tidak termasuk volume aspal yang cukup diserap agregat).

c) Fleksibilitas (kelenturan)

Fleksibilitas adalah kemampuan lapisan untuk mengikuti deformasi yang terjadi akibat beban lalulintas berulang tanpa timbulnya retak dan perubahan volume.

d) Tahan Geser/kekerasan (Skid Resistance)

Tahan geser adalah kekerasan yang diberikan oleh perkerasan sehingga tidak mengalami slip, baik diwaktu hujan atau basah maupun diwaktu kering, kekerasan dinyatakan dengan koefisien gesek antar permukaan jalan dengan ban kendaraan.

e) Ketahanan terhadap kelelehan

Ketahanan terhadap kelelehan adalah ketahanan dari lapisan atas aspal beton (Lataston) dalam menerima beban berulang tanpa terjadinya kelelehan yang berupa alur (Rutting) dan retak.

f) Kemudahan Pekerjaan (Workability)

Yang dimaksud dengan kemudahan pekerjaan adalah mudahnya suatu campuran untuk dihampar dan dipadatkan sehingga diperoleh hasil yang memenuhi kepadatan yang diharapkan.

Dalam pengujian karakteristik Hot Rolled Sheet - Base (HRS Base) dilakukan dengan tujuan untuk mengetahui sifat-sifat dari campuran tersebut. Pengujian itu antara lain dilakukan dengan: (1) uji stabilitas dengan alat uji Marshall; (2) uji perendaman Marshall untuk indeks perendaman. Agar diperoleh karakteristik campuran yang maksimal, maka harus dilakukan pengujian pada kondisi dimana persentase aspal dari campuran adalah optimum. (Sukirman,1999).

\section{METODE PENELITIAN}

Diagram alir penelitian diperlihatkan pada Gambar 1.

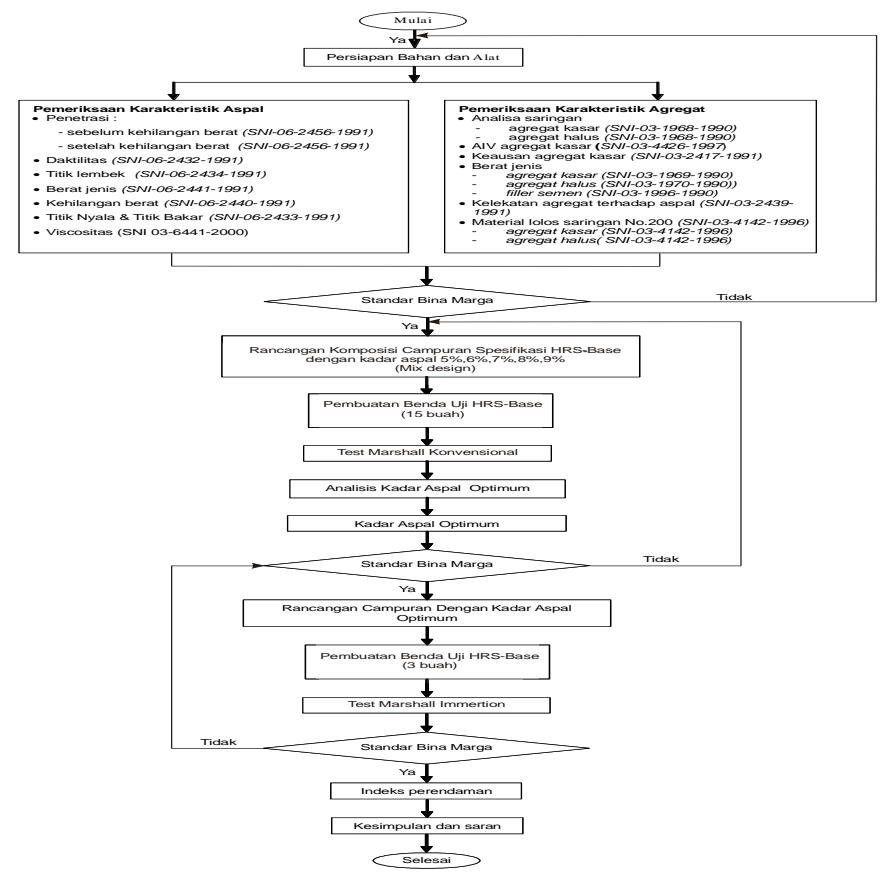

Gambar 1. Bagan Alir Penelitian 
Komposisi agregat benda uji HRS Base yang dibuat untuk penelitian diperlihatkan pada Gambar 2.

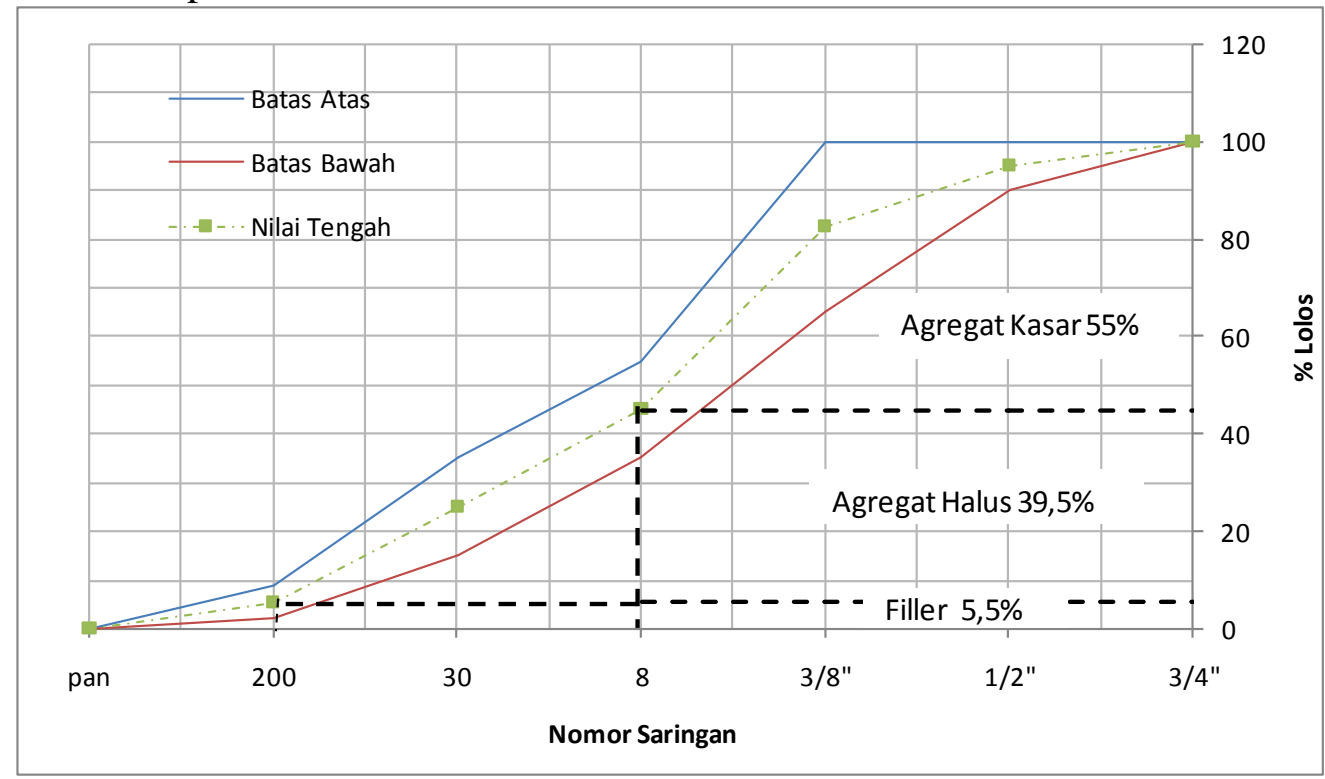

Gambar 2. Grafik Komposisi Agregat dalam Campuran

\section{Proporsi Aspal}

Kadar aspal yang digunakan dalam campuran HRS-Base, dapat diperoleh melalui perhitungan sebagai berikut :

Dimana :

$$
\mathrm{Pb}=0,035(\% \mathrm{CA})+0,045(\% \mathrm{FA})+0,18(\% \text { Filler })+\text { Konstanta }
$$

$\mathrm{Pb} \quad=$ Kadar aspal perkiraan

$\mathrm{CA}=$ Agregat kasar tertahan saringan No. 8

FA = Agregat halus lolos saringan No. 8 dan tertahan No. 200

Filler = Agregat halus lolos saringan No. 200

$\mathrm{K} \quad=$ Konstanta, diambil 0,5 - 1

Perhitungan kadar aspal perkiraan $(\mathrm{Pb})$ :

$\mathrm{Pb}=0,035(392)+0,045(98.995)+0,18(1,005)+1$

$=7,0029 \%=7 \%$

Maka rancangan komposisi campuran yang digunakan adalah dengan menambahkan dua kadar aspal keatas dan dua kadar aspal kebawah dari kadar aspal perkiraan. Kadar aspal tengah menjadi nilai patokan membuat benda uji untuk memperoleh nilai kadar aspal optimum (KSO). Adapun cara menentukan berat aspal dalam campuran pada masing-masing benda uji sebagai berikut:

$$
\text { Berat Aspal }(\mathrm{gr})=\frac{\mathrm{A} \%}{(100 \%-\mathrm{A} \%)} \times 1200 \mathrm{gr}
$$

Ket : A = Kadar Aspal

Tabel 2. Kadar Aspal Campuran HRS-Base

\begin{tabular}{|c|c|}
\hline Kadar Aspal (\%) & Berat Aspal (gr) \\
\hline 5 & 63.15 \\
\hline 6 & 76.59 \\
\hline 7 & 90.32 \\
\hline 8 & 104.34 \\
\hline 9 & 118.68 \\
\hline
\end{tabular}




\section{Komposisi total campuran}

Setelah diketahui komposisi agregat dalam campuran serta kadar aspal, maka kita dapat mengetahui komposisi total campuran yang akan digunakan pada campuran Hot Rolled Sheet - Base (HRS-Base).

Tabel 3. Komposisi Total Campuran HRS-Base

\begin{tabular}{|l|l|l|l|l|l|}
\hline Kadar Aspal (\%) & $5 \%$ & $6 \%$ & $7 \%$ & $8 \%$ & $9 \%$ \\
\hline Berat Agregat (gr) & 1200 & 1200 & 1200 & 1200 & 1200 \\
\hline Berat Aspal (gr) & 63.16 & 76.60 & 90.32 & 104.35 & 118.68 \\
\hline Total (gr) & 1263.15 & 1276.60 & 1290.32 & 1304.35 & 1318.68 \\
\hline
\end{tabular}

Tabel 4. Bulk Spesific Gravity Agregat, Effctive Spesific Gravity Agregat dan Filler Semen

\begin{tabular}{|l|c|c|c|c|}
\hline \multirow{2}{*}{ Gradasi Agregat } & \multicolumn{3}{|c|}{ Spesific Gravity } & $\begin{array}{c}\text { Komposisi } \\
\text { agregat }\end{array}$ \\
\cline { 2 - 5 } & Bulk & Semu & Efektif & $(\%)$ \\
\hline & $\mathrm{a}$ & $\mathrm{B}$ & $\mathrm{c}=(\mathrm{a}+\mathrm{b}) / 2$ & $\mathrm{D}$ \\
\hline Agregat Kasar & 2.68 & 2.71 & 2.70 & 55 \\
\hline Agregat Halus & 2.51 & 2.55 & 2.52 & 39.5 \\
\hline Filler ( Semen) & 3.09 & & & 5.5 \\
\hline & & & & 100 \\
\hline
\end{tabular}

Perhitungan Bulk Spesific Gravity Agregat :

$$
\begin{aligned}
& =\frac{100}{\left(\frac{\% \text { Agregat Kasar }}{\mathrm{BJ}_{\text {bulk }} \text { Agregat Kasar }}+\frac{\% \text { Agregat Halus }}{\mathrm{BJ}_{\text {bulk }} \text { Agregat Halus }}+\frac{\% \text { Filler }}{\text { BJ Filler }}\right)} \\
& =2.63
\end{aligned}
$$

Perhitungan Effective Spesific Gravity Agregat :

$$
=\frac{100}{\left(\frac{\% \text { Agregat Kasar }}{\mathrm{BJ}_{\text {efektif }} \text { Agregat Kasar }}+\frac{\% \text { Agregat Halus }}{\mathrm{BJ}_{\text {efektif }} \text { Agregat Halus }}+\frac{\% \text { Filler }}{\mathrm{BJ} \text { Filler }}\right)}=2.65
$$

Pembuatan Benda uji HRS-Base

Pada campuran Hot Rolled Sheet - Base (HRS-Base) yang menggunakan filler semen dibuat 18 benda uji. Adapun langkah-langkah pembuatannya adalah sebagai berikut :

a) Masing-masing agregat dikeringkan sampai beratnya tetap pada suhu (105 \pm 50$)$

${ }^{\circ} \mathrm{C}$. Setelah dingin, agregat disaringan menjad fraksi-fraksi yang dikehendaki, dan ditimbang sesuai komosisi.

b) Mencampur semua agregat dan filler semen menjadi satu, kemudian dipanaskan dalam panci pencampuran sampai suhu pencampuran $170^{\circ} \mathrm{C}$. sementara itu aspal juga dipanaskan pada tempat tersendiri dengan suhu $150{ }^{\circ} \mathrm{C}$.

c) Menuangkan aspal kedalam agregat dengan berat yang telah ditentukan, kemudian diaduk sampai homogen dan terlihat seluruh permukaan agregat tertutup oleh aspal. Suhu pencampuran diusahakan tetap $\left(160{ }^{\circ} \mathrm{C}\right)$, hal ini dapat dikontrol dengan menggunakan termometer.

d) Campuran yang telah homogen, dipindahkan kedalam cetakan benda uji (mold) yang telah dibersihkan dan pada alasnya diberi kertas saring terlebih dahulu. 
Memindahkan campuran kedalam mold dengan menggunakan bantuan corong aluminium yang diletakan diatas cetakan.

e) Selanjutnya campuran yang ada didalam mold tadi ditusuk-tusuk menggunakan spatula sebanyak 15 kali pada bagian pinggir cetakan secara keliling dan 10 kali pada bagian tengah. Kemudian diratakan permukaan campuran, kemudian diletakkan kertas saring diatasnya.

f) Memadatkan campuran dengan menggunakan alat pemadat, pemadatan dilakukan sebanyak 75 kali pada satu sisinya dan 75 kali pada sisi yang lainnya (75 tumbukan untuk lalulintas berat ).

g) Setelah itu benda uji didinginkan didalam mold selama 2-3 jam pada suhu ruang. Setelah dingin, benda uji dapat dikeluarkan dengan menggunakan alat ejektor, lalu diletakkan diatas permukaan yang rata serta memberikan kode pada benda uji dan diamkan selam 24 jam pada suhu ruang.

Campuran HRS-Base dalam penelitian ini menggunakan filler semen dan dibuat 18 benda uji, yagn dibuat berdasarkan standar Puslitbang Jalan dan Jembatan (2008). Ada tiga tahap pengujian yang dilakukan dari metode Marshall Konvensional yaitu melakukan pengukuran berat jenis, pengukuran stabilitas dan flow serta pengukuran kerapatan dan analisa rongga.

\section{Pengujian Marshall Konvensional}

a) Merendam benda uji dalam bak perendaman (Water Bath) selama 30-40 menit dengan suhu tetap $(60 \pm 1){ }^{\circ} \mathrm{C}$.

b) Benda uji dikeluarkan dari bak perendaman dan diletakkan kedalam segmen bawah kepala penekan dengan catatan bahwa waktu yang diperlukan dari saat diangkatnya benda uji dari bak perendaman sampai tercapainya beban maksimum tidak boleh melebihi 30 detik.

c) Memasang segmen atas di atas benda uji dan diletakkan keseluruhannya dalam mesin penguji.

d) Memasang arloji pengukuran pelelehan (Flow) pada kedudukannya di atas salah satu batang penuntun dan diatur kedudukan jarum penunjuk pada angka nol, sementara selubung tangki arloji (Sleeve) dipegang teguh terhadap segmen atas kepala penekan.

e) Menaikkan kepala penekan beserta benda ujinya sehingga menyentuh alas cincin penguji, sebelum pembebanan diberikan.

f) Mengatur jarum arloji tekan pada kedudukan angka nol.

g) Memberikan pembebanan pada benda uji dengan kecepatan tetap sekitar $50 \mathrm{~mm}$ per menit sampai Stabilitas dicapai.

h) Mencatat nilai pelelehan (Flow) yang ditunjukkan oleh jarum arloji pengukur pelelehan pada saat pembebanan maksimum tercapai.

i) Setelah itu dari data-data diatas dipakai untuk mencari kadar aspal optimum dan selanjutnya digunakan pada uji Marshall Immersion dengan 3 benda uji, dengan perendaman selama 24 jam.

\section{HASIL DAN PEMBAHASAN}

Hasil Pengujian agregat

Adapun pengujian yang dilakukan terhadap karakteristik agregat antara lain :

a) Analisa Saringan Agregat Kasar

Berat Bahan : 2500 gram 
Material: Cipping/Batu Pecah Tinoring

Tabel 5. Hasil Analisa Saringan Agregat Kasar

\begin{tabular}{|c|c|c|c|c|c|c|c|c|}
\hline \multirow[t]{2}{*}{ No. Saringan } & \multicolumn{2}{|c|}{$\begin{array}{l}\text { Berat Tertahan } \\
\text { (Gram) }\end{array}$} & \multicolumn{2}{|c|}{$\begin{array}{c}\text { Kumulatif Tertahan } \\
\text { (Gram) }\end{array}$} & \multicolumn{2}{|c|}{$\begin{array}{l}\text { Persen Total } \\
\text { Tertahan }(\%)\end{array}$} & \multicolumn{2}{|c|}{ Persen Lolos $(\%)$} \\
\hline & I & II & I & II & I & II & I & II \\
\hline 1 ', & 0 & 0 & 0 & 0 & 0 & 0 & 00 & 00 \\
\hline $3 / 4 "$ & 271 & 30 & 271 & 30 & .84 & .2 & .16 & 8.8 \\
\hline $1 / 2 "$ & 280 & 355 & 551 & 385 & .04 & 5.4 & .96 & 4.6 \\
\hline $3 / 8^{\prime \prime}$ & 536 & 744 & 2087 & 2129 & 83.48 & 85.16 & 16.52 & 14.84 \\
\hline No.8 & 413 & 371 & 2500 & 2500 & 100 & 100 & 0 & 0 \\
\hline No.30 & 0 & 0 & 2500 & 2500 & 100 & 100 & 0 & 0 \\
\hline No.50 & 0 & 0 & 2500 & 2500 & 100 & 100 & 0 & 0 \\
\hline No. 200 & 0 & 0 & 2500 & 2500 & 100 & 100 & 0 & 0 \\
\hline PAN & 0 & 0 & 2500 & 2500 & 100 & 100 & 0 & 0 \\
\hline
\end{tabular}

b) Analisa Saringan Agregat Halus
Berat Bahan
: 1000 gram
Material
: Pasir Maulu Tana Toraja

Tabel 6. Hasil Analisa Saringan Agregat Halus

\begin{tabular}{|l|c|c|c|c|c|c|c|c|}
\hline \multirow{2}{*}{$\begin{array}{c}\text { No } \\
\text { Saringan }\end{array}$} & \multicolumn{2}{|c|}{$\begin{array}{c}\text { Berat Tertahan } \\
\text { (Gram) }\end{array}$} & \multicolumn{2}{c|}{$\begin{array}{c}\text { Kumulatif Tertahan } \\
\text { (Gram) }\end{array}$} & \multicolumn{2}{c|}{$\begin{array}{c}\text { Persen Total } \\
\text { Tertahan } \\
(\%)\end{array}$} & \multicolumn{2}{c|}{$\begin{array}{c}\text { Persen Lolos } \\
(\%)\end{array}$} \\
\cline { 2 - 9 } & I & II & I & II & I & II & I & II \\
\hline $1 "$ & 0 & 0 & 0 & 0 & 0 & 0 & 100 & 100 \\
\hline $3 / 4 "$ & 0 & 0 & 0 & 0 & 0 & 0 & 100 & 100 \\
\hline $1 / 2 "$ & 0 & 0 & 0 & 0 & 0 & 0 & 100 & 100 \\
\hline $3 / 8 "$ & 0 & 0 & 0 & 0 & 0 & 0 & 100 & 100 \\
\hline No.8 & 0 & 0 & 0 & 0 & 0 & 0 & 100 & 100 \\
\hline No.30 & 528.8 & 646 & 528.8 & 646 & 52.88 & 64.6 & 47.12 & 35.4 \\
\hline No.50 & 386.8 & 279 & 915.6 & 925 & 91.56 & 92.5 & 8.44 & 7.5 \\
\hline No.100 & 62.8 & 50 & 978.4 & 975 & 97.84 & 97.5 & 2.16 & 2.5 \\
\hline No.200 & 11.59 & 14.94 & 989.99 & 989.94 & 99.00 & 98.99 & 1.00 & 1.01 \\
\hline PAN & 10.01 & 10.6 & 1000 & 1000 & 100 & 100 & 0 & 0 \\
\hline
\end{tabular}

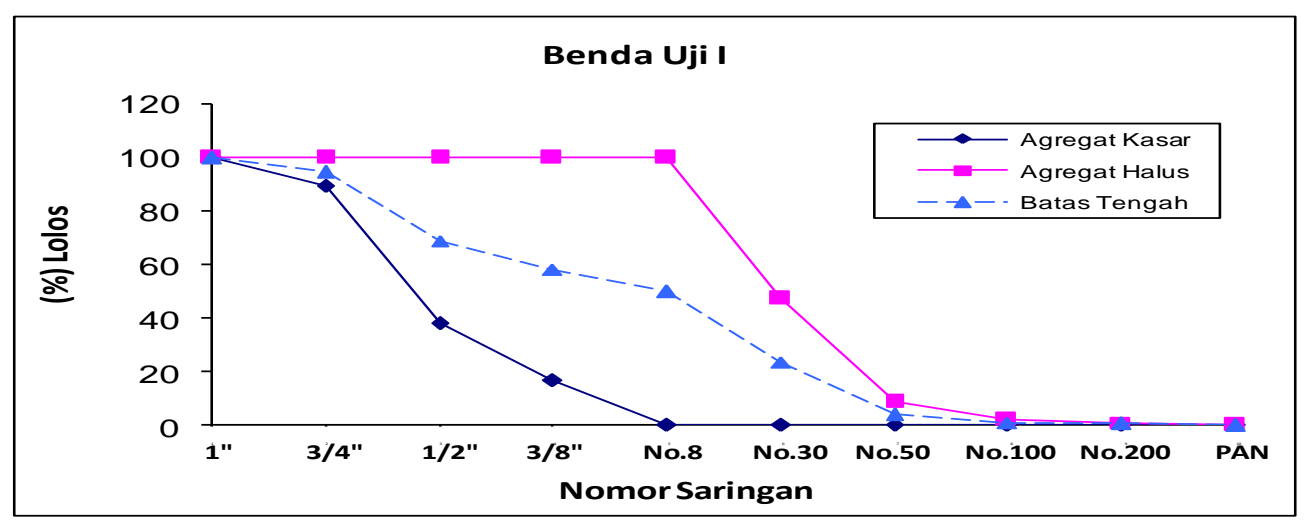

Gambar 3. Grafik Agregat Campuran untuk Benda Uji I 


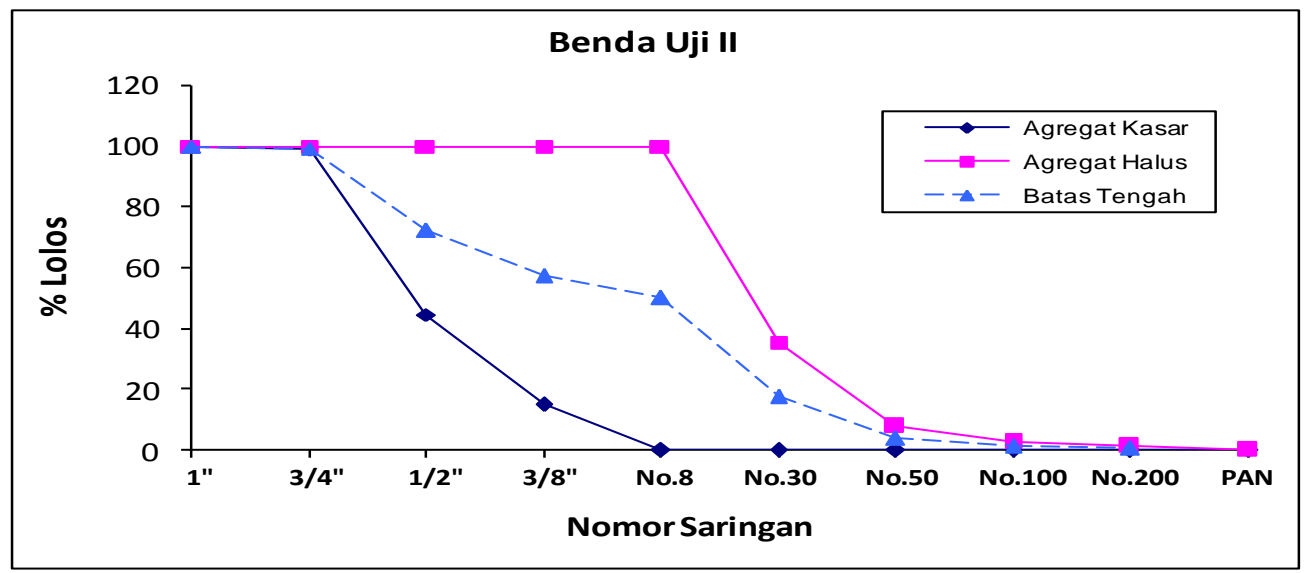

Gambar 4. Grafik Agregat Campuran untuk Benda Uji II

Hasil Pengujian Kekuatan Agregat Terhadap Tumbukan (Aggregate Impact Value)

Tabel 7. Hasil Pengujian Kekuatan Agregat Terhadap Tumbukan (Aggregate Impact Value)

\begin{tabular}{|c|c|c|c|c|c|c|}
\hline \multirow{3}{*}{ Jenis Pemeriksaan } & \multirow{3}{*}{ Cara Pemeriksaan } & \multirow{2}{*}{\multicolumn{2}{|c|}{$\begin{array}{r}\text { Hasil Uji } \\
\text { Sampel }\end{array}$}} & \multicolumn{2}{|c|}{$\begin{array}{l}\text { Spesifikasi } \\
\text { Bina Marga }\end{array}$} & \multirow{3}{*}{ 胥 } \\
\hline & & & & \multirow{2}{*}{ Min } & \multirow{2}{*}{ Maks } & \\
\hline & & $\mathrm{I}$ & II & & & \\
\hline $\begin{array}{ll}\text { Agregat } & \text { terhadap } \\
\text { tumbukan } & \\
\end{array}$ & SNI 03-4426-1997 & 1,66 & 2,62 & & 30 & $\%$ \\
\hline \multicolumn{2}{|c|}{ Nilai Ketahanan Terhadap Tumbukan Rata-rata } & \multicolumn{2}{|c|}{$2.14 \%$} & & & \\
\hline
\end{tabular}

Tabel diatas menunjukkan hasil pengujian kekuatan agregat terhadap tumbukan, dan hasil uji sampel satu didapatkan 1,66\% dan sampel dua didapatkan $2,62 \%$, dan nilai rata-rata yang didapatkan $2.14 \%$, sedangkan nilai batasan yang ditentukan oleh Bina Marga adalah batasan maksimum yaitu 30\%. Jadi dari nilai rata-rata yang didapatkan dari hasil uji tersebut memenuhi syarat yang ditetapkan.

Hasil Pengujian Keausan Dengan Alat Abrasi Los Angeles.

Tabel 8. Hasil Pengujian Keausan Agregat

\begin{tabular}{|l|l|l|l|l|l|}
\hline \multirow{2}{*}{ Jenis Pemeriksaan } & \multirow{2}{*}{ Cara Pemeriksaan } & Hasil Uji & \multicolumn{2}{|l|}{$\begin{array}{l}\text { Spesifikasi } \\
\text { Bina Marga }\end{array}$} & \multirow{2}{*}{ Satuan } \\
\cline { 3 - 5 } & & Sampel & Min & Maks & \\
\hline Nilai Ketahanan & & & & & \\
Agregat Terhadap & & & & & \\
Keausan : & SNI 03-2417- & & & & \\
Fraksi A & 1991 & 20,36 & & & \\
Fraksi B & & 15,44 & & 40 & $\%$ \\
Fraksi C & & 13,28 & - & & \\
Fraksi D & & 14,8 & & & \\
\hline
\end{tabular}

Pada pengujian keausan terdapat empat fraksi yaitu fraksi A,B,C dan D. Adapun penentuan fraksi, tergantung pada banyaknya bola baja yang dimasukkan ke dalam mesin Los Angeles, dengan batasan maksimal yang ditetapkan oleh Bina Marga adalah $40 \%$. Jika diperhatikan dari hasil uji masing-masing fraksi, semuanya memenuhi spesifikasi. 
Hasil Pengujian Berat Jenis dan Penyerapan Agregat

Tabel 9. Hasil Pengujian Berat Jenis dan Penyerapan Agregat Kasar

\begin{tabular}{|c|c|c|c|c|c|}
\hline \multirow{2}{*}{ Jenis Pemeriksaan } & \multirow{2}{*}{ Cara Pemeriksaan } & $\begin{array}{l}\text { Hasil Uji } \\
\text { Rata-Rata }\end{array}$ & \multicolumn{2}{|c|}{$\begin{array}{l}\text { Spesifikasi } \\
\text { Bina Marga }\end{array}$} & \multirow{2}{*}{ 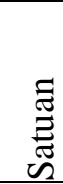 } \\
\hline & & $\begin{array}{l}\text { Sampel } \\
\text { I \& II }\end{array}$ & Min & Maks & \\
\hline Berat Jenis Bulk & \multirow{4}{*}{ SNI 03-1969-1990 } & 2,68 & 2.5 & - & \\
\hline Berat Jenis SSD & & 2,69 & 2.5 & - & \\
\hline Berat Jenis Semu & & 2,71 & 2.5 & - & \\
\hline Penyerapan Air & & 0.35 & - & 3 & $\%$ \\
\hline
\end{tabular}

Pada hasil pengujian berat jenis dan penyerapan agregat kasar di atas, hasil uji rata-rata semuanya masuk dalam spesifikasi. Ini dibuktikan dengan nilai batasan yang ditetapkan Bina Marga untuk berat jenis dengan nilai minimum 2,5\%, dan untuk penyerapan dengan nilai maksimum $3 \%$.

Hasil Pengujian Berat Jenis dan Penyerapan Halus

Tabel 10. Hasil Pengujian Berat Jenis dan Penyerapan Agregat Halus

\begin{tabular}{|c|c|c|c|c|c|}
\hline \multirow{3}{*}{ Jenis Pemeriksaan } & \multirow{3}{*}{ Cara Pemeriksaan } & $\begin{array}{l}\text { Hasil Uji } \\
\text { Rata-Rata }\end{array}$ & \multicolumn{2}{|c|}{$\begin{array}{l}\text { Spesifikasi Bina } \\
\text { Marga }\end{array}$} & \multirow{3}{*}{ 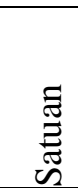 } \\
\hline & & Sampel & \multirow{2}{*}{ Min } & \multirow{2}{*}{ Maks } & \\
\hline & & I \& II & & & \\
\hline Berat Jenis Bulk & \multirow{4}{*}{ SNI 03-1970-1990 } & 2,51 & 2.5 & - & \\
\hline Berat Jenis SSD & & 2,525 & 2.5 & - & \\
\hline Berat Jenis Semu & & 2,55 & 2.5 & - & \\
\hline Penyerapan Air & & 0,65 & - & 3 & $\%$ \\
\hline
\end{tabular}

Spesifikasi Bina Marga tidak mencantumkan nilai batasan untuk berat jenis dan penyerapan terhadap agregat halus sebab agregat halus yang diuji merupakan pecahan dari agregat kasar (pecahan induk) maka nilai batasan minimum dan maksimum mengikuti nilai batasan untuk agregat dari terak dan dari hasil uji diatas, berat jenis maupun penyerapan semua masuk dalam batasan yang ditentukan.

\section{Hasil Pengujian Kadar Lumpur Pasir}

Tabel 11. Hasil Pengujian Kadar Lumpur Pasir (Pasir Maulu)

\begin{tabular}{|c|c|c|c|c|c|}
\hline \multirow{2}{*}{ Jenis Pemeriksaan } & \multirow{2}{*}{$\begin{array}{l}\text { Cara } \\
\text { Pemeriksaan }\end{array}$} & \multirow{2}{*}{$\begin{array}{ll}\begin{array}{l}\text { Hasil Uji Rata- } \\
\text { rata }\end{array} \\
\text { Sampel } \\
\text { I \& II }\end{array}$} & \multicolumn{2}{|c|}{$\begin{array}{ll}\text { Spesifikasi } & \text { Bina } \\
\text { Marga } & \\
\end{array}$} & \multirow[b]{2}{*}{$\begin{array}{l}\tilde{\Xi} \\
\text { Eే } \\
\text { : }\end{array}$} \\
\hline & & & Min & Maks & \\
\hline Sand Equivalen & SNI 03-4428-1997 & 99,01 & 50 & - & $\%$ \\
\hline Kadar Lumpur & SNI 03-4428-1997 & 0,99 & - & 50 & $\%$ \\
\hline
\end{tabular}

Pada hasil pemeriksaan Sand Equivalen hasil uji rata-rata didapatkan 99,01\%, sementara Bina Marga hanya menetapkan batasan minimum saja yaitu 50\%, sedangkan hasil pemeriksaan Kadar Lumpur didapatkan 0,99\% dan batasan maksimal dalam spesifikasi adalah 50\%. Dari nilai hasil uji diatas keduanya masuk dalam batasan yang ditetapkan.

Hasil Pengujian Karakteristik Campuran Hot Rolled Sheet-Base (HRS-Base) Adapun analisa dan pembahasan hasil pengujian-pengujian diatas adalah sebagai berikut : 


\section{1) Analisa Terhadap VIM (Void in Mix)}

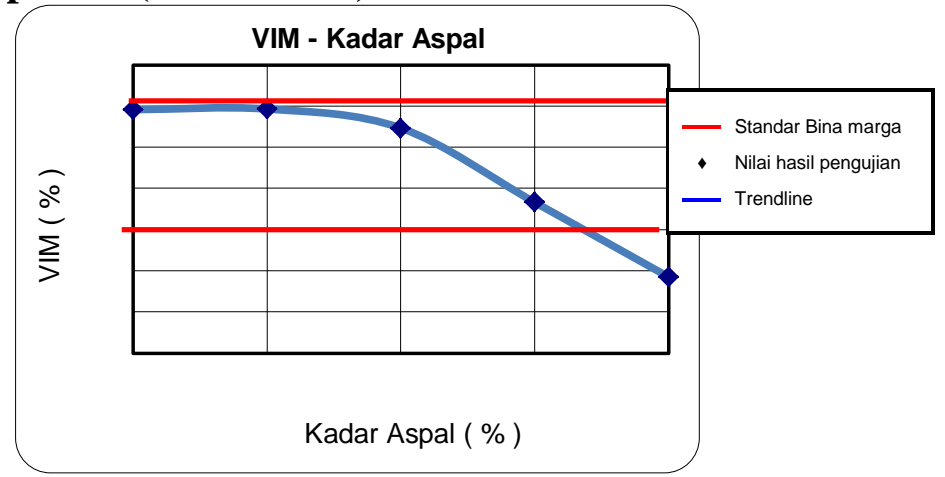

Gambar 5. Grafik Perbandingan antara VIM dengan Kadar Aspal

VIM adalah volume total udara yang berada diantara partikel agregat yang terselimuti aspal dalam suatu perkerasan yang telah dipadatkan (rongga dalam campuran), dinyatakan dengan persen volume bulk suatu perkerasan. Dari hasil pengujian di laboratorium diperoleh nilai VIM seperti tabel 4.20.

Tabel 12. Nilai VIM dari Hasil Pengujian Karakteristik Marshall HRS - Base

\begin{tabular}{|l|l|l|l|l|l|}
\hline Kadar Aspal (\%) & $5 \%$ & $6 \%$ & $7 \%$ & $8 \%$ & $9 \%$ \\
\hline Nilai VIM (\%) & 5.91 & 5.93 & 5.46 & 3.66 & 1.85 \\
\hline
\end{tabular}

Standar VIM dari Puslitbang Jalan dan Jembatan (2011) nilai minimumnya $3 \%$ dan maksimum adalah 6\%. Nilai VIM yang didapatkan untuk campuran HRSBase, pada kadar aspal 5\% sampai $8 \%$ memenuhi standar yang ditetapkan, sedangkan kadar aspal 9\% tidak memenuhi standar. Hal ini disebabkan, semakin banyak aspal maka rongga dalam campuran makin kecil pula.

\section{2) Analisa Terhadap Stabilitas Lataston / HRS - Base}

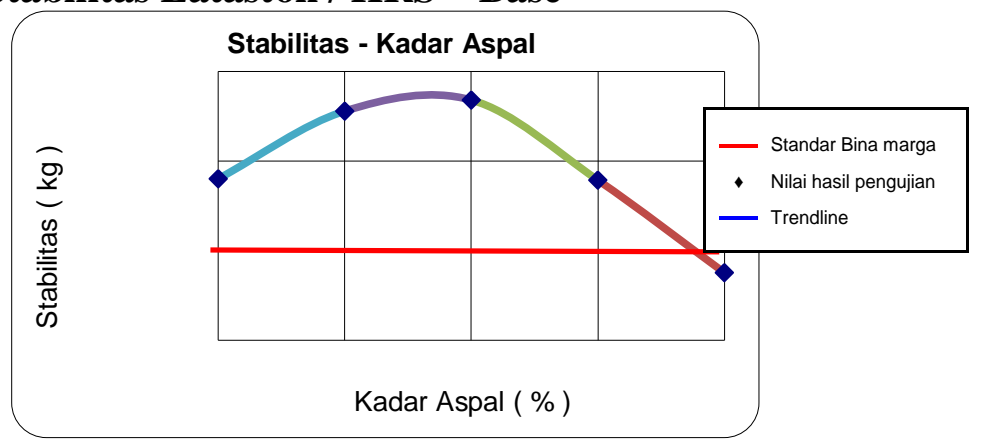

Gambar 6. Grafik Perbandingan antara Stabilitas dengan Kadar Aspal

Stabilitas adalah kemampuan/kekuatan suatu campuran menerima atau menahan beban/ tekanan lalu lintas tanpa terjadi perubahan bentuk seperti gelombang, alur maupun bleeding (pengumpulan aspal di permukaan perkerasan) yang dinyatakan dalam satuan berat (kilogram). Dari hasil pengujian di laboratorium diperoleh nilai stabilitas seperti tabel 13.

Tabel 13. Nilai Stabilitas dari Hasil Pengujian Karakteristik Marshall HRS - Base

\begin{tabular}{|l|l|l|l|l|l|}
\hline Kadar Aspal (\%) & $5 \%$ & $6 \%$ & $7 \%$ & $8 \%$ & $9 \%$ \\
\hline Stabilitas (kg) & 880.55 & 956.03 & 968.44 & 879.04 & 775.72 \\
\hline
\end{tabular}

Standar Puslitbang Jalan dan Jembatan (2011), nilai stabilitas minimum adalah $800 \mathrm{~kg}$, sedangkan nilai yang didapat dari hasil pengujian di laboratorium 
bervariasi. Nilai stabilitas tersebut memperlihatkan kenaikan pada kadar aspal 5\% sampai pada kadar aspal $7 \%$, dan mengalami penurunan pada kadar aspal $8 \%$ dan 9\%. Hal ini disebabkan karena makin besar kadar aspalnya maka nilai stabilitasnya akan semakin besar pula, tetapi jika kadar aspal itu terlalu banyak maka akan menurunkan nilai stabilitas campuran HRS-Base tersebut. Aspal akan menyelimuti dan merekatkan agregat dengan baik pada jumlah tertentu, sehingga stabilitasnya maksimum. Tetapi jika aspal bertambah lagi maka selaput aspal pada permukaan agregat menjadi tebal sehingga jarak antara agregat semakin renggang yang menyebabkan interlocking (kuncian) antara agregat menjadi jelek dan menyebabkan stabilitasnya menurun.

\section{3) Analisa Terhadap Flow}

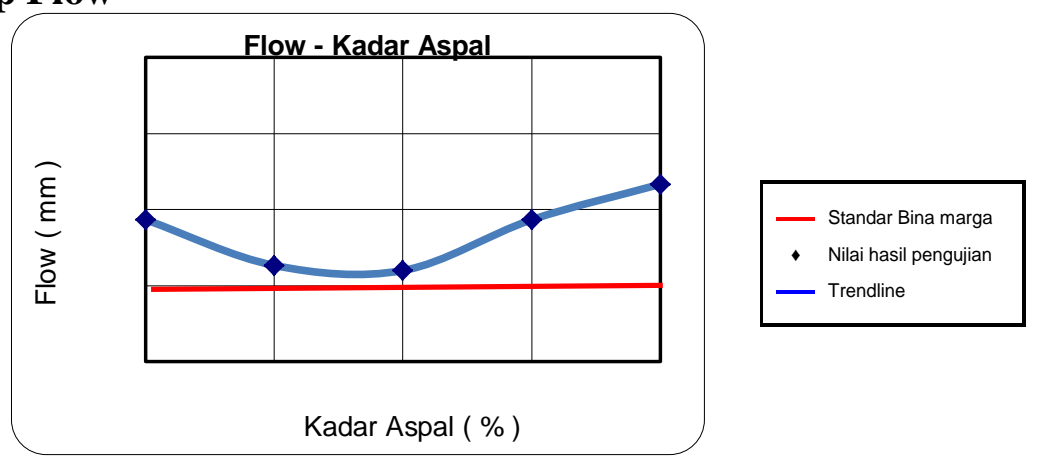

Gambar 7. Grafik Perbandingan antara Flow dengan Kadar Aspal

Flow adalah besarnya perubahan bentuk plastis suatu benda uji campuran beraspal yang terjadi akibat suatu beban sampai batas keruntuhan, dinyatakan dalam satuan panjang.hasil pengujian di laboratorium diperoleh nilai flow seperti tabel 5.10.

Tabel 14. Nilai Flow dari Hasil Pengujian Karakteristik Marshall HRS -Base

\begin{tabular}{|l|l|l|l|l|l|}
\hline Kadar Aspal (\%) & $5 \%$ & $6 \%$ & $7 \%$ & $8 \%$ & $9 \%$ \\
\hline Flom (mm) & 3.43 & 3.13 & 3.10 & 3.43 & 3.67 \\
\hline
\end{tabular}

Standar Puslitbang Jalan dan Jembatan (2011) yaitu nilai minimumnya adalah 3,0 mm. Nilai-nilai flow di atas semuanya memenuhi standar tersebut. Bila diperhatikan nilai flow diatas sangat bervariasi dan jika kita lihat mulai dari kadar aspal 7\%-9\% nilai flow semakin besar karena semakin bertambah aspal maka selimut aspal atau selaput aspal pada permukaan agregat semakin tebal yang menyebabkan nilai kelenturan (flow) bertambah besar.

\section{4) Analisa Terhadap MQ (Marshall Quotient)}

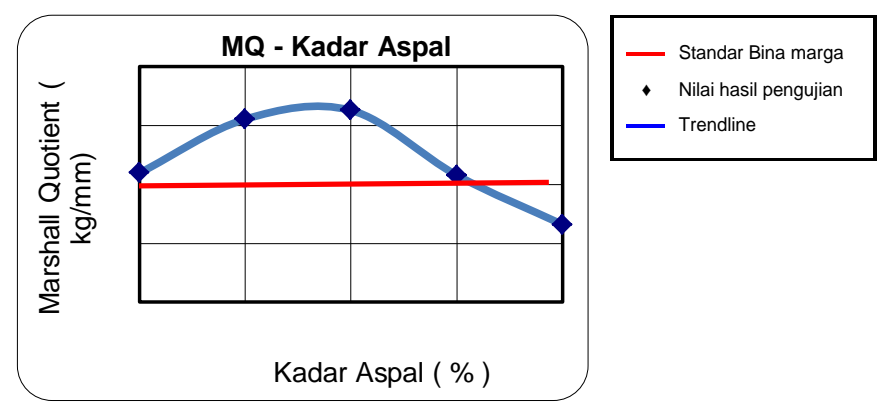

Gambar 8. Grafik Perbandingan antara MQ dengan kadar aspal 
MQ adalah nilai hasil bagi antara stabilitas dan flow, juga merupakan nilai untuk memperlihatkan ketahanan campuran terhadap pembebanan setiap mm dari campuran.

Tabel 15. Nilai MQ dari Hasil Pengujian Karakteristik Marshall HRS - Base

\begin{tabular}{|l|l|l|l|l|l|}
\hline Kadar Aspal (\%) & $5 \%$ & $6 \%$ & $7 \%$ & $8 \%$ & $9 \%$ \\
\hline MQ & 259.54 & 305.24 & 312.76 & 257.68 & 215.83 \\
\hline
\end{tabular}

Hasil nilai MQ, terlihat hasil yang sangat bervariasi, yaitu mengalami kenaikan pada kadar $5 \%$ sampai pada kadar aspal 7\% dan kembali mengalami penurunan pada kadar aspal $8 \%$ dan 9\%. Namun demikian nilai MQ diatas, pada kadar aspal 5\% sampai 8\% memenuhi standar Puslitbang jalan dan jembatan (2008) yang menetapkan nilai MQ untuk lalu lintas berat minimal $250 \mathrm{~kg} / \mathrm{mm}$.

\section{5) Analisa Terhadap VMA (Void in Mineral Aggregate)}

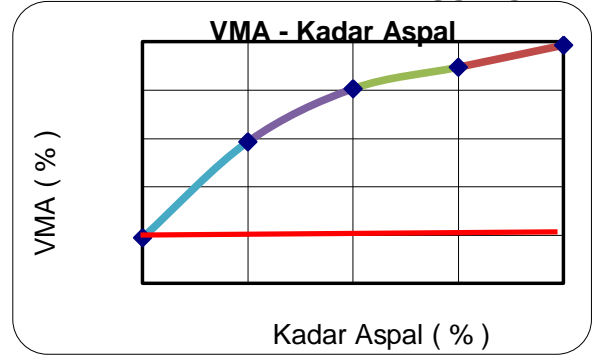

$$
\begin{aligned}
& \text { - Standar Bina marga } \\
& \text { - Nilai hasil pengujian } \\
& \text { - Trendline }
\end{aligned}
$$

Gambar 9. Grafik Perbandingan VMA dengan kadar aspal

VMA adalah volume rongga yang terdapat diantara butir-butir agregat suatu campuran beraspal padat, yaitu rongga udara dan volume kadar aspal efektif (rongga dalam agregat), dinyatakan dalam \% volume total benda uji. Volume agregat dihitung dari berat jenis bulk (bukan berat jenis efektif atau berat jenis nyata).

Tabel 16. Nilai VMA dari Hasil Pengujian Karakteristik Marshall HRS - Base

\begin{tabular}{|l|l|l|l|l|l|}
\hline Kadar Aspal (\%) & $5 \%$ & $6 \%$ & $7 \%$ & $8 \%$ & $9 \%$ \\
\hline VMA & 17.20 & 19.17 & 20.03 & 20.48 & 20.93 \\
\hline
\end{tabular}

Jika dibandingkan standar Puslitbang Jalan dan Jembatan (2011), nilai VMA untuk campuran HRS-Base yang ditetapkan yaitu minimum 17\%, maka nilai yang di dapat dari hasil pengujian dilaboratorium masuk dalam standar yang ditetapkan/disyaratkan.

\section{6) Hasil Pengujian Marshall Immertion}

Marshall immersion adalah salah satu pengujian untuk melihat durabilitas (ketahanan terhadap beban dan pengaruh suhu) atau keawetan suatu campuran, hasil dari pengujian ini adalah rasio stabilitas. Rasio tersebut dibandingkan dengan stabilitas dari benda uji marshall setelah direndam dalam suhu $60^{\circ} \mathrm{C}$ dalam waterbath selama 24 jam terhadap stabilitas benda uji marshall dengan 30 menit, yang biasa disebut indeks perendaman (IP) atau indeks kekuatan sisa (IKS).

Indeks Perendaman (Marshall Immertion)

$$
\begin{aligned}
\text { IP } & =\frac{\text { Stabilitas Marshall Immertion }}{\text { Stabilitas Marshall Konvensional }} \times 100 \% \\
& =\frac{810.07}{968.44} \times 100 \%
\end{aligned}
$$




$$
\begin{aligned}
& =83.65 \% \\
& 83.65 \% \geq 75 \%
\end{aligned}
$$

Dari hasil pengujian Marshall Immertion diperoleh indeks perendaman sebesar $83.65 \%$. Nilai indeks perendaman ini telah memenuhi standar yang ditetapkan oleh Bina Marga yaitu $\geq 75 \%$. Berdasarkan nilai tersebut dapat disimpulkan bahwa perkerasan jalan yang menggunakan Agregat Batu Kapur Tinoring sebagai Agregat dalam campuran HRS-Base dapat tahan terhadap suhu dan lamanya perendaman air.

\section{PENUTUP}

Kekuatan agregat terhadap tumbukan sebesar 2,14\%, dimana standar maksimum adalah 30\%; Abrasi Los Angeles fraksi A, B, C dan D masing-masing adalah $20,36 \%, 15,44 \%, 13,28 \%$ dan $14,8 \%$ sementara standar maksimum $40 \%$; Berat Jenis (BJ) Bulk, BJ SSD dan BJ semu adalah 2,68\%, 2,69\%, 2,71\% sementara standar nilai minimum adalah 2,5\%; Penyerapan air $0,35 \%$ sementara standar maksimum 3\%. Hal tersebut menunjukkan bahwa batu kapur Tinoring memenuhi standar sebagai agregat kasar campuran aspal HRS-Base.

Jika dibandingkan dengan standar campuran aspal Puslitbang Jalan dan Jembatan (2011), maka Karakteristik HRS-Base dengan agregat kasar batu kapur yang memenuhi syarat adalah campuran dengan kadar aspal adalah 5\%, 6\%, 7\% dan $8 \%$ dengan kadar aspal optimum $7 \%$.

\section{DAFTAR PUSTAKA}

Anonim, 2011, Modul Pengujian dan Perencanaan Campuran Beraspal, Puslitbang Jalan dan Jembatan, Bandung.

Anonim, 1991, Metode Pengujian Campuran Aspal dengan Alat Marshall, SNI 062489-1991.

Anonim, 1987, Petunjuk Pelaksanaan Lapisan Aspal Beton (Laston) untuk Jalan Raya, Departemen Pekerjaan Umum Bina Marga, Jakarta.

Tm, Suprapto, 2004, Bahan dan Struktur Jalan Raya, Penerbit UGM, Yogyakarta. 
PENA TEKNIK: Jurnal Ilmiah Ilmu-Ilmu Teknik

Volume 1, Nomor 1, Maret 2016: 81 - 94 